\title{
ASAS NEBIS IN IDEM DALAM PUTUSAN HAKIM DALAM PERKARA POLIGAMI DI PENGADILAN NEGERI PASAMAN SEBAGAI CERIMINAN IUS CONSTITUTUM
}

\author{
GOKMA TONI PARLINDUNGAN S \\ STIH Padang
}

\begin{abstract}
Usually the achievement is still at the stage of family formation or household formation, because it can be measured quantitatively. Whereas qualitatively that is happy and eternal can not be achieved, even not achieved at all. This is evident from the many divorces, betel marriages, and polygamy and this has an impact on the status and position of marriage, children and property. Such conditions are very alarming, because on the one hand marriage is a sacred institution, but on the other hand marriage does not have a sacred meaning, because it is triggered by various factors, including the economy.
\end{abstract}

Keywords: Nebis In Idem, Judge's Decision, Polygamy, Pasaman.

\begin{abstract}
Abstrak: tujuan perkawinan tidak selalu dapat tercapai secara utuh. Biasanya tercapainya masih dalam taraf pembentukan keluarga atau pembentukan rumah tangga, karena dapat diukur secara kuantitatif. Sedangkan secara kualitatif yaitu bahagia dan kekal belum dapat dicapai, bahkan tidak tercapai sama sekali. Hal ini terbukti dari banyaknya perceraian, nikah sirih, dan poligami dan hal ini mempunyai akibat terhadap status dan kedudukan perkawinan, anak dan harta benda. Kondisi demikian sangat memprihatinkan, karena di satu sisi perkawinan adalah lembaga yang sakral, namun pada sisi lain perkawinan tidak mempunyai arti yang sakral, karena dipicu oleh berbagai faktor, antara lain ekonomi.
\end{abstract}

Kata Kunci: Nebis In Idem, Putusan Hakim, Poligami, Pasaman.

\section{A. Pendahuluan}

Adanya hakim yang baik ini tentunya diharapkan vonis yang diambilnya akan memenuhi harapan para pihak yang mengantungkan harapannya pada hakim di sidang pengadilan dan harapan itu terwujut melalui vonis hakim yang dapat diterima oleh semua pihak atau dengan kata lain tidak ada lagi hal-hal lain yang akan menjadi perbincangan yang kurang menyenangkan bagi para pihak yang bermasalah. Memang benar bahwa hakim jugalah manusia yang tidak akan luput dari salah atau kehilafan. Termasuk dalam hal ini saat hakim memutuskan perkara pidana poligami. Hakim sebelum memutuskan suatu perkara dalam bentuk vonis tentunya sudah melalui pertimbangan sebagaimana yang diatur dalam Pasal 184 KUHAP. Namun demikian setelah yang bersangkutan (terpidana) menjalani hukumannya, mantan terpidana tersebut kembali melanjutkan hubungan perkawinannya dengan orang yang dikawini kedua tersebut atau dengan kata lain melanjutkan perkawinannya yang tertunda karena menjalankan vonis hakim berupa hukuman penjara, padahal perbuatan itu sebelumnya nyata-nyata dikatakan sebagai suatu perbuatan yang salah atau merupakan suatu kejahatan, namun tiada satu ketentuanpun yang dapat menyalahkannya atas perbuatan melanjutkan hubungan perkawinannya itu. Hal ini terjadi karena telah dibatasi oleh asas $\mathrm{Ne}$ bis in idem yang berlaku dalam lingkup hukum publik. Ne bis in idem yang 
artinya: orang tidak boleh dituntut sekali lagi lantaran perbuatan atau peristiwa yang bagiannya telah diputuskan oleh hakim.

Adapun tujuan dari nebis in idem ini adalah: 1) Jangan sampai pemerintah berulang-ulang membicarakan tentang peristiwa yang sama itu juga sehingga dalam satu peristiwa ada beberapa putusan-putusan yang rupa-rupa yang akan mengurangkan kepercayaan rakyat terhadap pemerintahnya; 2) Sekali orang sebagai terdakwa harus diberi ketenangan hati janganlah orang dibiarkan terus menerus dengan perasaan terancam oleh bahaya penuntutan kembali dalam peristiwa yang sekali telah diputuskan.

Dengan adanya fenomena seperti ini, tentunya untuk para pencari keadilan yang pada umumnya kaum hawa, tentunya rasa keadilan belum tercapai baginya karena perbuatan yang sudah nyata salah berdasarkan putusan hakim tersebut namun perkawinan tetap masih dapat dilanjutkan lagi. Hal ini tidak tertutup kemungkinan dapat menimbulkan kemarahan bagi pihak yang merasa dirugikan atau paling tidak merupakan suatu bahan pembicaraan bagi orang lain yang mengetahui perkara tersebut, jika ini terjadi maka perkara tersebut dapat menimbulkan beberapa persoalan, antara lain apakah putusan hakim dalam perkara poligami memenuhi maksud ketentuan hukum asas tentang pemidanaan yang seharusnya dapat tercapainya tujuan dari penegakan hukum yaitu dapat memberikan rasa keadilan, kepastian hukum dan kemanfaatan bagi pihak yang mencarinya dan apakah setelah terpidana perkara poligami selesai menjalankan pidananya yang bersangkutan dibenarkan melanjutkan hubungan perkawinannya?.

Penegakan hukum pada prinsipnya harus dapat memberi manfaat atau berdaya guna (utility) bagi masyarakat, namun di samping itu masyarakat juga mengharapkan adanya penegakan hukum untuk mencapai suatu keadilan. Kendatipun demikian tidak dapat kita pungkiri, bahwa apa yang dianggap berguna (secara sosiologis) belum tentu adil, begitu juga sebaliknya apa yang dirasakan adil (secara filosopis), belum tentu berguna bagi masyarakat. Sehubungan dengan hal tersebut Jimly Asshiddiqie menyatakan masyarakat hanya menginginkan adanya suatu kepastian hukum, yaitu adanya suatu peraturan yang dapat mengisi kekosongan hukum tanpa menghiraukan apakah hukum itu adil atau tidak. Dalam pelaksanaan penegakan hukum, keadilan harus diperhatikan, namun hukum itu tidak identik dengan keadilan, hukum itu bersifat umum, mengikat setiap orang, bersifat menyamaratakan. Setiap orang yang mencuri harus dihukum tanpa membeda-bedakan siapa yang mencuri. Sebaliknya keadilan bersifat subjektif, individualistis dan tidak menyamaratakan. Adil bagi seseorang belum tentu dirasakan adil bagi orang lain.

Senada dengan hal tersebut Jimly Asshiddiqie, menambahkan bahwa hukum tidak dapat kita tekankan pada suatu nilai tertentu saja, tetapi harus berisikan berbagai nilai. Hukum itu harus memenuhi berbagai karya disebut sebagai nilai dasar dari hukum. Nilai dasar hukum tersebut adalah: keadilan, kegunaan dan kepastian hukum. Meskipun ketiga-tiganya itu merupakan nilai dasar dari hukum, namun di antara terdapat suatu spannungsverhaltnis (ketegangan), oleh karena di antara ketiga nilai dasar hukum tersebut masing-masing mempunyai tuntutan yang berbeda satu sama lainnya, sehingga ketiganya mempunyai potensi untuk saling bertentangan, untuk itulah proses penegakan hukum oleh aparat penegak hukum diharapkan mampu menjembatani nilai-nilai dasar tersebut, tidak salah bila kita mengingat ahli hukum dari belanda Taverne pernah mengatakan,"Geef me goede Rechters, goede Rechters 
Commissarissen, goede Officieren Van Justitie en goede Politie Ambtenaren, en ik zal met een slecht wetboek van strafprocesrecht goed bereiken" Berikan saya hakim yang baik, hakim pengawas yang baik, jaksa yang baik, dan polisi yang baik, maka penegakan hukum akan berjalan walaupun dengan hukum pidana yang buruk.

\section{B. Metodologi Penelitian}

Penelitian yang dilaksanakan oleh penulis dengan mengunakan metode penelitian hukum dalam ruang lingkup deskriptif yaitu suatu usaha untuk menggambarkan tentang pertimbangan hakim dalam menjatuhkan putusan terhadap perkara poligami di Pengadilan Negeri Pariaman. Dalam hal untuk meneliti berupa putusan hakim dalam Penerapan hukum yang menyangkut pemidanaan berdasarkan putusan pengadilan dalam tindak pidana poligami, rencana penelitian yang akan dilakukan oleh penulis adalah studi kasus di Pengadilan Negeri Pariaman. Penelitian yang dilakukan oleh penulis dengan mengunakan pendekatan yuridis normatif atau dengan cara meneliti bahan Pustaka. Dalam hal penelitian yang dilakukan dengan cara mempelajari bahanbahan hokum primer dan sekunder yang nantinya akan dijadikan pedoman dalam memahami dan menganalisis permasalahan yang dibahas, sedangkan sebagai pendukung utama digunakan pendekatan empris, dimana juga akan diteliti penerapan hukum dalam praktis khususnya penerapan hukum yang menyangkut pemidanaan dan hal yang terjadi setelah pemidanaan dijalankan oleh terpidana dalam tindak pidana poligami.

\section{Hasil dan Pembahasan}

Seperti diketahui melekat asas ne bis in idem kepada suatu perkara apabila perkara tersebut telah diputus sebelumnya yaitu putusannya positif yang sudah mempunyai kekuatan hukum tetap kemudian perkara tersebut diajukan kembali dengan subjek dan pokok perkara yang sama. Kemudian muncul suatu pemikiran bagaimanakah apabila asas ne bis in idem tersebut diterapkan dalam kasus atau perkara perceraian? Perkara perceraian tentu berbeda dengan perkara perdata lainnya, dimana unsur nurani atau kenyamanan hati dalam berumah tangga yang membuat perkara perceraian ini berbeda dengan perkara lain. Apakah seseorang yang mengajukan gugatan perceraian kepada suami atau istrinya kemudian ternyata gugatan tersebut ditolak oleh hakim, apakah selanjutnya seseorang tersebut di masa yang akan datang tidak dapat mengajukan gugatan perceraian kepada suami atau istrinya karena berbenturan dengan asas ne bis in idem tersebut.

Mengenai penerapan asas ne bis in idem dalam Perkara Perceraian ada dua pandangan mengenai apakah dalam suatu perkara perceraian dapat diterapkan asas $n e$ bis in idem? Tentu pandangan tersebut mempunyai alasan yang kuat dan masingmasing mempunyai dasar berfikir yang jelas. Apabila misalnya seorang suami mengajukan gugatan perceraian kepada istrinya dengan dasar sering terjadi percekcokan kemudian oleh majelis hakim perkara tersebut ditolak kemudian tentu apabila perkara tersebut diajukan kembali oleh suami untuk menggugat cerai istrinya dengan dasar yang sama dikemudian hari maka tentu perkara tersebut melekat unsur asas ne bis in idem karena dalam perkara perceraian subjek selalu sama dan tentu bisa saja materi percerainnya bisa sama karena tidak ada yang dapat menjamin suatu perceraian dengan dasar percekcokan kemudian ditolak oleh majelis hakim kemudian dikumudian percekcokan tidak terjadi lagi.

Beberapa Advokat berpendapat bahwa apabila suatu perkara perceraian yang telah ditolak oleh hakim kemudian diajukan kembali oleh subjek yang sama dan E-ISSN: 2657-0300 Lembaga Penelitian dan Penerbitan Hasil Penelitian Ensiklopedia 3 
tentunya dengan masalah yang dan dengan alasan yang sama maka perkara tersebut melekat asas ne bis in idem karena unsur-unsur atau syarat-syarat ne bis in idem terpenuhi dalam perkara tersebut sebagaimana ditentukan dalam Pasal 1917 KUH Perdata. Akan tetapi beradasarkan Surat Edaran Makhamah Agung No. 03 Tahun 2002 tentang penanganan yang berkaitan dengan asas ne bis in idem yang pada intinya berisikan bahwa Hakim Pengadilan Negeri dan Hakim Pengadilan Tinggi harus berhati-hati menerapkan asas ne bis in idem terhadap perkara yang berkaitan dengan asas ne bis in idem.

Bahwa dengan adanya Surat Edaran tersebut maka Penulis berpendapat bahwa dalam suatu perkara perceraian yang berkaitan dengan asas ne bis in idem tidak dapat semata-mata diterapkan asas ne bis in idem. Penulis berpendat bahwa perkara perceraian adalah perkara yang tidak dapat disamakan dengan perkara lainnya dalam penerpan asas ne bis idem, karena dalam perkara perceraian melibatkan unsur dari hati nurani atau emosi dari suatu subjek hukum sehingga tidak ada yang dapat menjamin bahwa unsur dari Pasal 19 Huruf f Peraturan Pemerintah No. 9 Tahun 1975 tentang Peraturan Pelaksanaan Undang-Undang No. 1 Tahun 1974 tentang Perkawinan tidak terjadi lagi dikemudian hari karena tentu saja suatu masalah yang sudah selesai saat ini dikemudian hari bisa saja terulang kepada subjek tersebut.

Bahwa sebagai contoh dalam Penelitian ini Penulis mengambil Putusan Perkara Perceraian di Pasaman Barat dengan Nomor Register: 29/Pid.B/2008/PN.PSB yang menyatakan: Menimbang, bahwa dengan demikian seluruh unsur pasal dalam dakwaan kesatu telah terpenuhi oleh perbuatan terdakwa, maka terdakwa harus dinyatakan terbukti secara sah dan menyakinkan bersalah melakukan tindak pidana sebagaimana didakwakan dalam dakwaan ksetau tesebut dan dakwaan berikutnya tidak perlu dipertimbangkan lagi; Menimbang, bahwa tidak ada hal-hal yang dapat menghapuskan pidana terhadap diri terdakwa baik alasan pemaaf maupun alasan pembenar, maka oleh karena itu terdakwa harus dijatuhi pidana yang setimpal dengan perbuatannya; Menimbang, bahwa terhadap terdakwa pernah dilakukan penahanan maka masa penahanan yang teah dijalani oleh terdakwa akan dikurangkan seluruhnya dari pidana yang dijatuhkan dan selanjutnya cukup alasan bagi Majelis Hakim untuk memerintahkan agar terdakwa tetap ditahan; Menimbang, bahwa barang bukti yang diajukan di persidangan, statusnya akan ditentukan dalam amar putusan ini setelah mempertimbangkan keadaan, sifat kepentingan terhadap barang bukti tersebut; Menimbang, bahwa oleh karena terdakwa dipidana maka harus pula untuk membayar biaya perkara; Menimbang, bahwa majelis sebelum majelis menjatuhkan pidana terlebih dahulun harus dipertimbangkan hal-hal yang memberatkan dan meringankan.

Bahwa dalam Putusan Pengadilan Negeri Pasaman Barat tersebut Penulis tidak sependapat karena Majelis Hakim melihat sudut pandang yang SUBJEKTIF karena hanya melihat sudut pandang dari Pihak Istri tidak melihat sudut pandang dari Pihak Suami yang telah mengalami beban moril akibat dari permasalahan yang berkepanjangan bahkan hingga sampai tingkat Pengadilan pun tidak berhasil mendamaikan antara Suami dengan istri dimana sesuai dengan isi gugatan sebelumnya antara Suami dengan istri telah sering terjadi perselisihan dan percekcokan yang berakibat perpisahan sekian lamanya dan telah menjalani kehidupan masing-masing, lalu serta keinginan atau niatan yang penuh dari Suami untuk berpisah dengan Istri .

Bahwa hal-hal tersebut yang telah disebutkan sebelumnya mengenai alasan perkawinan antara Suami dengan Istri tidak bisa lagi dipertahankan sehingga Suami 
mengajukan gugatan cerai terhadap Istri telah memenuhi bunyi Pasal 19 huruf f Peraturan Pemerintah No.9 Tahun 1975 tentang pelaksanaan Undang-Undang No.1 Tahun 1974 tentang Perkawinan yang berbunyi: Bunyi Pasal 19 PP No.9 Tahun 1975 huruf f: "antara suami dan isteri terus menerus terjadi perselisihan dan pertengkaran dan tidak ada harapan akan hidup rukun lagi dalam rumah tangga". Bahwa menilik Pertimbangan Hakim Pengadilan Negeri Pasaman Tersebut tersebut, Penulis sependapat karena Majelis Hakim tidak hanya melihat dari sudut pandang perkara tersebut mengandung ne bis in dem atau tidak akan tetapi melihat mengapa gugatan cerai sampai diajukan hingga kedua kalinya yang berarti Majelis melihat bahwa memang rumah tangga sebagaimana dalam Putusan tersebut sudah tidak layak dipertahankan dan demi kenyaman bagi Suami maupun istri dalam menjalani kehidupan. Bahwa dengan adanya jenis Putusan tersebut, maka Penulis berpendapat belum adanya kesapahaman diantara para Hakim-hakim sendiri dalam menentukan perkara perceraian apakah dapat diterapkan asas ne bis in idem, sehingga mengakibatkan kebingungan tersendiri bagi Para Pencari Keadilan yang merasa sudah tidak nyaman dengan keadaan rumah tangganya oleh karena itu Makhmah Agung harus membuat terobosan hukum bagi hukum perkawinan khususnya dalam penerapan asas ne bis in idem dalam perkara perceraian.

Kepastian hukum terpidana perkara poligami selesai menjalankan pidananya yang bersangkutan dibenarkan melanjutkan hubungan perkawinannya diatur dalam Undang-Undang Nomor 1 Tahun 1974 Tentang Perkawianan Disebutkan bahwa Perkawinan sebagai "ikatan lahir dan bathin antara seorang pria dengan seorang wanita sebagai suami isteri dengan tujuan membentuk keluarga yang bahagia dan kekal berdasarkan Ketuhanan Yang Maha Esa". Definisi tersebut di atas secara tegas dinyatakan bahwa perkawinan mempunyai hubungan yang erat dengan agama/rohani, jasmani/biologis, hukum/sosial.

Pertama dari sisi hukum, perkawinan bukan hanya sekedar untuk keabsahan melakukan persetubuhan, tetapi lebih jauh dari itu bertujuan untuk mencapai sesuatu yang lebih luhur karena memang perkawinan itu dipandang sebagai sebuah persetujuan perikatan atau kontrak. Kedua, secara sosial, perkawinan itu sendiri berhasil mengangkat derajat seorang wanita ke tingkat yang lebih tinggi di masyarakat dibanding dengan kondisinya sebelum melangsungkan perkawinan. Ketiga, perkawinan dari sudut pandang agama merupakan sesuatu yang suci dan sakral, untuk itu perkawinan harus dilakukan oleh orang-orang yang suci agar tujuan perkawinan yang luhur itu dapat tercapai. Selanjutnya, yang lebih penting adalah bahwa dalam sudut pandang agama perkawinan merupakan langkah awal untuk membentuk keluarga sebagai asas masyarakat.

Dapat dipahami bahwa perkawinan sebagai langkah awal untuk membentuk keluarga, yang selanjutnya kumpulan keluarga inilah yang akan membentuk warga masyarakat yang pada akhirnya menjadi sebuah Negara. Dapat dikatakan jika perkawinan itu dilangsungkan sesuai dengan peraturan agama dan perundangundangan, maka bisa dipastikan akan terbentuk keluarga-keluarga yang baik. Pada gilirannya negarapun akan menjadi baik. Hukum perkawinan berada dalam barisan hukum keluarga, yaitu suatu bidang yang "sensitif" atau non-netral yang tidak mudah untuk berubah. Norma-normanya terlanjur dipandang ideal sehingga jarang tersentuh oleh tuntutan empiris. Padahal, sebagai suatu norma hukum yang hidup dalam masyarakat, ia tidak pernah lepas dari pergeseran kepentingan.

Pembentukan keluarga adalah mutlak lewat perkawinan. Peristiwa hukum tersebut adalah peristiwa yang sengaja dilahirkan dan dikehendaki oleh pria dan E-ISSN: 2657-0300 Lembaga Penelitian dan Penerbitan Hasil Penelitian Ensiklopedia 5 
perempuan dengan ikatan lahir batin sebagai suami isteri dengan tujuan untuk membentuk keluarga yang bahagia dan kekal (Pasal 1 UUP). Pasal 2 Kompilasi Hukum Islam (KHI) bahwa "Pernikahan yaitu akad yang sangat kuat atau mitsaqan qhalidhan untuk mentaati perintah Allah dan melaksanakannya". Hal ini sejalan dengan apa yang diatur dalam Pasal 33 UUP, yang secara tegas mengatakan bahwa, "Suami isteri saling cinta mencintai, hormat menghormati, setia dan memberi bantuan lahir bathin yang satu kepada yang lain”. Hal senada juga diatur dalam Pasal 77 ayat (2) KHI yang berbunyi, "Suami isteri wajib saling cinta mencintai, hormat menghormati, setia dan memberi bantuan lahir bathin yang satu dengan yang lain". Ketentuan tentang perkawinan sudah diunifikasikan melalui Undang-Undang Perkawinan Nomor 1 Tahun 1974 tentang Perkawinan (UUP). Perkawinan yang sah bertitik tolak pada ketentuan Pasal 2 ayat (1) UUP yang menggaris bawahi, "Perkawinan adalah sah apabila dilakukan menurut hukum masing-masing agama dan kepercayaan itu," dan Pasal 2 ayat (2) UUP yang mengatakan, "Tiap-tiap perkawinan dicatat menurut peraturan perundang-undangan yang berlaku."

Kedua ayat dari Pasal 2 UUP tersebut dapat ditafsirkan dua model. Pertama, tidak berdiri sendiri dan penerapannya kerap ditafsirkan kumulatif mutlak, tetapi dalam kenyataan diartikan terpisah atau berdiri sendiri sehingga punya konsekuensi logis tersendiri. Kedua, memiliki hubungan yang unik. Pandangan pertama menyatakan bahwa tafsir makna keabsahan perkawinan bersumber pada ayat (1), sedangkan ayat (2) hanya syarat administratif. Pandangan ke-dua menyatakan bahwa keabsahan pada ayat (1) tidak bisa dipisahkan dengan ketentuan ayat (2) karena keduanya secara kumulatif menjadi syarat sah perkawinan. Proses pencatatan perkawinan yang ditekankan dalam Undang Undang Perkawinan bersifat tertutup, memaksa dan mengikat masyarakat, dalam arti tidak dapat dilanggar. Hal ini tampak dari penegasan di dalam Ketentuan Penutup (Pasal 66) yang menyatakan, "Untuk perkawinan dan segala sesuatu yang berhubungan dengan perkawinan berdasarkan atas undang-undang ini dan peraturan lain yang mengatur tentang perkawinan sejauh telah diatur dalam undang-undang ini, dinyatakan tidak berlaku."

Selanjutnya pada Pasal 7 UUP, terdapat persyaratan-persyaratan yang lebih rinci. Berkenaan dengan calon mempelai pria dan wanita, undang-undang mensyaratkan batas minimum umur calon suami sekurang-kurangnya berumur 19 tahun dan calon istri sekurang-kurangnya berumur 16 tahun. Dalam hal adanya penyimpangan terhadap Pasal 7 Undang Undang Perkawinan, dapat dilakukan dengan meminta dispensasi kepada pengadilan atau pejabat lain, yang ditunjuk oleh kedua orang tua pihak pria maupun pihak wanita. Perkawinan menurut Undang Undang Perkawinan menganut asas monogami tidak mutlak, bahwa dalam suatu perkawinan seorang pria hanya boleh mempunyai seorang isteri. Begitu pula sebaliknya, seorang wanita hanya boleh mempunyai seorang suami (Pasal 3 ayat (1) UUP). Dianutnya asas ini mengandung arti bahwa terbuka peluang untuk melakukan poligami dibatasi secara ketat dan terbatas bahwa seorang suami mempunyai lebih dari satu isteri apabila ia untuk itu telah mendapat dispensasi. Hal ini menjadi syarat berikutnya yang diatur dalam Pasal 3 ayat (2) UUP menyatakan bahwa, "Pengadilan berwenang memberi izin kepada seorang suami untuk beristeri lebih dari seorang apabila dikehendaki oleh pihak-pihak yang bersangkutan."

Persyaratan memperoleh dispensasi ini, selanjutnya suami harus memenuhi ketentuan yang terdapat pada Pasal 4 dan Pasal 5 UUP. Secara garis besar kedua pasal 
tersebut dapat dikatakan harus adanya izin pengadilan setempat; apabila isteri tidak dapat menjalankan kewajiban; cacat badan atau penyakit yang tidak bisa disembuhkan; tidak dapat mempunyai keturunan. Selanjutnya, memposisikan suami untuk bertanggung jawab terhadap perkawinan sebelumnya yaitu perjanjian dari isteri, kepastian hukum dan jaminan yang adil kepada isteri-isteri dan anak-anak mereka. Berdasarkan Pasal 3 ayat (2) Undang Undang Perkawinan terdapat keharusan adanya persetujuan isteri merupakan syarat mutlak yang harus dipenuhi oleh seorang suami yang akan beristeri lebih dari satu dan syarat ini seringkali menjadi persoalan utama dalam poligami, dimana seorang suami melakukan perkawinan untuk kedua kalinya atau lebih tanpa izin dari isteri yang pertama. Perkawinan ini biasanya dilakukan di bawah tangan atau disebut nikah sirih. Sayangnya, kedudukan nikah sirih bertolak belakang dengan ketentuan Pasal 4 dan Pasal 5 UUP.

Bilamana suami melanggar ketentuan Pasal 3 ayat (2) Undang Undang Perkawinan, isteri sah mempunyai hak dan berkewajiban untuk melaporkan suaminya melakukan pernikahan kedua tanpa izin darinya, maka dalam hal ini suami dapat dikategorikan telah melakukan tindak pidana, seperti yang diatur dalam Pasal 279 dan Pasal 280 Undang-Undang Nomor 1 Tahun 1946 tentang Kitab Undang-Undang Hukum Pidana. Pasal 280 ini berisi sebagai berikut, yaitu "Barangsiapa mengadakan perkawinan, padahal sengaja tidak memberitahu kepada pihak lain bahwa ada penghalang yang sah, diancam dengan pidana penjara paling lama lima tahun, apabila kemudian berdasarkan penghalang tersebut, perkawinan lalu dinyatakan tidak sah".

\section{Penutup}

Dalam kenyataannya, tujuan perkawinan tidak selalu dapat tercapai secara utuh. Biasanya tercapainya masih dalam taraf pembentukan keluarga atau pembentukan rumah tangga, karena dapat diukur secara kuantitatif. Sedangkan secara kualitatif yaitu bahagia dan kekal belum dapat dicapai, bahkan tidak tercapai sama sekali. Hal ini terbukti dari banyaknya perceraian, nikah sirih, dan poligami dan hal ini mempunyai akibat terhadap status dan kedudukan perkawinan, anak dan harta benda. Kondisi demikian sangat memprihatinkan, karena di satu sisi perkawinan adalah lembaga yang sakral, namun pada sisi lain perkawinan tidak mempunyai arti yang sakral, karena dipicu oleh berbagai faktor, antara lain ekonomi.

\section{Daftar Pustaka}

Abdul Nasir Taufiq Al 'Atthar, Poligami di Tinjau dari Segi Agama, Sosial dan Perundang-Undangan, Bulan Bintang, Jakarta, 1976.

Achmad Ali, 2009, Menguak Teori Hukum (Legal Theory) dan Teori Peradilan (Judicialprudence) Termasuk Interpretasi Undang-Undang (Legisprudence), Kencana, Jakarta.

Ade Maman Suherman, 2004, Pengantar Perbandingan Sistem Hukum, Rajawali Press, Jakarta.

Andi Hamzah, 2009, Perbandingan Hukum Pidana Beberapa Negara, Edisi 3, PT. Sinar Grafika, Jakarta.

Barda Nawawi Arif, 2001, Masalah Penegakan Hukum dan Kebijakan Penanggulangan Kejahatan, Citra Adtya Bakti, Bandung.

Chazawi Adam, Pelajaran Hukum Pidana, Bagian 1 ; Stelsel Pidana, Teori-Teori Pemidanaan \& Batas Berlakunya Hukum Pidana, Raja Grafindo, Jakarta, 2008. 
Christian Andy Nugroho, Kajian Yuridis Terhadap Putusan Hakim Pengadilan Negeri Surakarta Dalam Tindak Pidana Penipuan Secara Berlanjut, Jurnal Mahasiswa, Fakultas Hukum Uiversitas Sriwijaya, Palembang, 2016.

Djaja S Meliala dan Nasar Ambarita, Azas Nebis in Idem (Apakah Dapat Diterapkan dalam Kasus Perceraian?), Lembaga Penelitian dan Pengabdian Kepada Masyarakat Unversitas Katolik Parahyangan, Bandung, 2013.

E.Y.Kanter dan S.R.Sintauri, 2002, Pengantar Hukum Pidna, Storia Grafika, Jakarta.

G. Peter Hoefnagels, 1969, The Other Side of Criminology, An Inversion of The Concept of Crime, Kluwer Academic Publisher, Holland.

H.S.A. Alhamdani, Risalah Nikah, Raja Murah, Pekalongan, 1980.

I Wayan Pathiana, Hukum Pidana Internasional, Yrama Widya, Bandung, 2006.

J.H. Merryman, 1985, The Civil Law Tradition: An Introduction to The Legal System of Western Europe and Latin Amerika, Standford University Press, California.

Jimly Asshiddiqie, Pembangunan Hukum dan Penegakan Hukum di Indonesia, disampaikan pada acara seminar "menyoal Moral Penegak hukum" dalam rangka Lustrum XI Fakultas Hukum Universitas Gadja Mada, Surabaya, tanggal 17 Februari 2006.

Mardjono Reksodiputro, 1993, Sistem Peradilan Pidana Indonesia: Melihat pada Kejahatan dan Penegakan Hukum Dalam Batas-Batas Toleransi, Makalah dalam Pidato Pengukuhan Guru Besar Tetap Universitas Indonesia, FHUI, Jakarta

Salim, H.S, 2012, Perkembangan Teori Dalam Ilmu Hukum, Rajawali Press, Jakarta.

Sohari Sahrani Tihami, Fikh Munakahat : Kajian Fiqh Nikah Lengkap, Rajawali Pers, Jakarta, 2010.

Sudikno Mertokusumo, 1993, Bab-bab Tentang Penemuan Hukum, Citra Aditya Bakti, Yogyakarta.

United Nations Office on Drugs Crime (UNODC), United Nations Congresses on Crime Prevention and Criminal Justice 1955-2010, 55 Years of Achievement, United Nations Information Service, Austria, 2010. 